University of Nebraska - Lincoln

DigitalCommons@University of Nebraska - Lincoln

2010

\title{
APPARENT SURVIVAL OF BREEDING WESTERN SANDPIPERS ON THE YUKON-KUSKOKWIM RIVER DELTA, ALASKA
}

\author{
Matthew Johnson \\ U.S. Geological Survey, matthew_johnson@usgs.gov \\ Daniel R. Ruthrauff \\ U.S. Geological Survey \\ Brian J. McCaffery \\ U.S. Fish and Wildlife Service \\ Susan M. Haig \\ U.S. Geological Survey, Susan_Haig@usgs.gov \\ Jeffrey R. Walters \\ Virginia Polytechnic Institute and State University
}

Follow this and additional works at: https://digitalcommons.unl.edu/usgsstaffpub

Johnson, Matthew; Ruthrauff, Daniel R.; McCaffery, Brian J.; Haig, Susan M.; and Walters, Jeffrey R., "APPARENT SURVIVAL OF BREEDING WESTERN SANDPIPERS ON THE YUKON-KUSKOKWIM RIVER DELTA, ALASKA" (2010). USGS Staff -- Published Research. 696.

https://digitalcommons.unl.edu/usgsstaffpub/696

This Article is brought to you for free and open access by the US Geological Survey at DigitalCommons@University of Nebraska - Lincoln. It has been accepted for inclusion in USGS Staff -- Published Research by an authorized administrator of DigitalCommons@University of Nebraska - Lincoln. 


\title{
APPARENT SURVIVAL OF BREEDING WESTERN SANDPIPERS ON THE YUKON-KUSKOKWIM RIVER DELTA, ALASKA
}

\author{
MATTHEW JOHNSON, ${ }^{1,5}$ DANIEL R. RUTHRAUFF, ${ }^{2}$ BRIAN J. MCCAFFERY, ${ }^{3}$ \\ SUSAN M. HAIG, ${ }^{1}$ AND JEFFREY R. WALTERS ${ }^{4}$
}

\begin{abstract}
We used 8 years of live recapture data (1998-2005) to estimate apparent annual survival for male $(n=$ $237)$ and female $(n=296)$ Western Sandpipers (Calidris mauri) breeding on a 36-ha plot on the Yukon-Kuskokwim River Delta, western Alaska. Apparent annual survival $(\Phi)$ is the product of true survival and site fidelity, and estimates of $\Phi$ were corrected for the probability of encounter. Overall return rates (individual returned to the study site in a subsequent season) were lower for females $(40 \%)$ than males $(65 \%)$, as was $\Phi$ ( \pm SE, females $=0.65 \pm 0.05$, males $=0.78 \pm 0.03$ ), and encounter rate (females $=0.51 \pm 0.07$, males $=0.74 \pm 0.04$ ). Results differed from previous estimates of $\Phi$ for this species as our estimates of $\Phi$ were higher for both males and females compared to estimates from another breeding site and two nonbreeding locations. Disparity among $\Phi$ estimates from breeding and nonbreeding areas highlights the need to delineate site-specific factors throughout the annual cycle that influence population dynamics of the Western Sandpiper. Received 30 May 2009. Accepted 9 October 2009.
\end{abstract}

Twenty-one percent of the world's 155 shorebird species are listed as species of conservation concern by Birdlife International (Piersma et al. 1997, Johnson and Oring 2002, Sandercock 2003). Several long-term studies have revealed population declines among migratory shorebirds (Charadriiformes) in Europe (Tucker and Heath 1994, Hagemeijer and Blair 1997), North America (Howe et al. 1989, Morrison et al. 2001, Haig et al. 2005), and Asia (Rose and Scott 1997). The Western Sandpiper (Calidris mauri) is considered a species of high conservation concern despite being one of the most abundant shorebirds in the Western Hemisphere (Bishop et al. 2000, Morrison et al. 2000, Brown et al. 2001). Declining numbers during spring (Butler and Lemon 2001) and fall migration surveys (Neil 1992, Butler and Lemon 2001) at staging areas in British Columbia and Texas coupled with a limited breeding distribution and threats to nonbreeding habitat have led to this conservation assessment (Brown et al. 2001, Fernández et al. 2006). However, reported declines in numbers at staging sites may be caused by shifts in migration patterns and not

\footnotetext{
${ }^{1}$ U.S. Geological Survey, Forest and Rangeland Ecosystem Science Center, 3200 Southwest Jefferson Way, Corvallis, OR 97331, USA.

${ }^{2}$ U.S. Geological Survey, Alaska Science Center, 4210 University Drive, Anchorage, AK 99508, USA.

${ }^{3}$ U.S. Fish and Wildlife Service, Yukon Delta National Wildlife Refuge, P. O. Box 346, Bethel, AK 99559, USA.

${ }^{4}$ Department of Biological Sciences, Virginia Polytechnic Institute and State University, Blacksburg, VA 24061, USA.

${ }^{5}$ Corresponding author;

e-mail: matthew_johnson@usgs.gov
}

impacts of demographic rates on population growth (Ydenberg et al. 2004).

The life history of migratory shorebirds is generally characterized by delayed maturity, low productivity, and relatively high adult survivorship (Evans and Pienkowski 1984, Piersma and Baker 2000). Robust estimation of demographic parameters is central to understanding population dynamics of avian species (Eberhardt 1985, Lande 1988, Clobert and Lebreton 1991). Estimation of survival rate is particularly important because the persistence of any animal population is the result of a balance between recruitment of new breeders into the population via reproduction and immigration, and losses due to the emigration and mortality of established breeders (Lebreton et al. 1993, Lieske et al. 2000). Estimation of these parameters and identification of ecological factors that affect avian populations requires long-term studies of marked individuals (Lebreton and North 1993).

A better understanding of shorebird demography would facilitate conservation efforts; however, population models have been developed for only a few shorebird species. Sensitivity analyses have found that adult survival often has the highest elasticity value and potentially the greatest impact on population growth rates (Hill and Carter 1991, Hitchcock and Gratto-Trevor 1997, Reed et al. 1998, Plissner and Haig 2000, Larson et al. 2002, Sandercock 2003). Effective conservation of migratory shorebirds requires reliable estimates of annual survival rates, but estimates are available for $<10 \%$ of shorebird species worldwide (Sandercock 2003). 
Western Sandpipers breed along the coasts of western Alaska and eastern Siberia and are distributed over a large geographic area in nonbreeding areas ranging on the Pacific Coast from California to Peru, and on the Atlantic Coast from New Jersey to Suriname (Wilson 1994). Male Western Sandpipers spend the nonbreeding season at more northerly latitudes compared to females (Page et al. 1972, Harrington and Haase 1994, Buenrostro et al. 1999, Nebel et al. 2002), and males generally precede females north during spring migration (Holmes 1971, Senner et al. 1981, Butler et al. 1987) with the opposite pattern during fall migration (Butler et al. 1987, Ydenberg et al. 2005). Comparative studies within their nonbreeding distribution have revealed divergent life history strategies (O'Hara et al. 2005). Juveniles and females from the southern portion of the nonbreeding range are more likely to remain at nonbreeding sites during their first breeding season compared to adults and males at northerly sites. This suggests Western Sandpiper life history varies with first-year females favoring increased survival and first-year males emphasizing initial breeding opportunities (O'Hara et al. 2005). Given the species' expansive geographic distribution and age-and gender-specific variation in life history strategies, it is likely Western Sandpipers likewise exhibit region-, age-, and gender-specific variation in survival.

Our objective was to produce estimates of apparent annual survival at a representative breeding site in the middle of the breeding range of Western Sandpipers in western Alaska. We used 8 years of live recapture data to examine whether apparent annual survival rate varied between males and females at our study site, and whether apparent survival varied significantly during the course of this study. We compare our estimates with those from a more northerly breeding site and two nonbreeding sites.

\section{METHODS}

Study Area and Field Methods.-We studied breeding Western Sandpipers at the Yukon Delta National Wildlife Refuge's Kanaryarmiut Field Station, Yukon-Kuskokwim River Delta, Alaska $\left(61^{\circ} 22^{\prime} \mathrm{N}, 165^{\circ} 07^{\prime} \mathrm{W}\right)$. We used a 36-ha study plot in dry upland tundra habitat along the Kuyungsik River (lowland moist low scrub community, Jorgenson and Ely 2001) to address our objectives. The study site supports an average of 80 breeding pairs annually (Johnson et al. 2005). Two to four observers searched this study plot daily from early May through late July from 1998 to 2005 for banded birds, nests, and broods. We banded each adult at the nest with a U.S. Geological Survey identification band and unique color combinations (3 UV-stable color bands/bird). We recaptured all birds when band loss or discoloration occurred ( $2 \%$ of all banded birds), indentified the individual by its U.S. Geological Survey identification band, and re-banded the bird with new color bands. Adults were classified as male or female by culmen length during banding ( $>93 \%$ of all birds; Page and Fearis 1971, Carter 1984). Birds were classified as males or females via behavior (courtship displays, copulation position) and comparison with their mate (females $>$ males) when culmen length was inconclusive (24$25 \mathrm{~mm}$ ). Locations of nests and banded individuals were mapped using geographic information system layers in ArcGIS (ESRI 2007) and nests were monitored through hatch, predation, or abandonment. It is possible to differentiate first-year Western Sandpipers that hatched in the previous breeding season from birds that are $\geq 2$ years old based on plumage characteristics (Sandercock et al. 1999). However, our sample of first-year birds was limited (24\% of females and $17 \%$ of males banded were first-year birds), and previous attempts to estimate apparent survival in this population revealed unacceptable overdispersion when fitting age-specific models to the data set $(\hat{c}>8 ; \mathrm{M}$. Johnson, unpubl. data). We chose not to estimate apparent survival by age class (i.e., first-year and $\geq 2$ year old birds), and instead estimated apparent survival for all breeding adults.

Statistical Analyses.-We used Cormack-JollySeber mark-recapture models to estimate apparent annual survival $(\Phi)$ corrected for probability of encounter $(p)$. Apparent survival rate was the probability that a bird alive in breeding season $i$ survived until the following breeding season $(i+$ 1) and returned to our study plot. Encounter probability was the probability that we detected a bird given that it was alive. Losses from the breeding population may result from permanent emigration or mortality, and are the complement of apparent survival. We conducted mark-recapture analysis following methodologies outlined by Burnham and Anderson (1998) using Program MARK (Version 4.2, Cooch and White 2004).

We incorporated gender (sex) and time-dependence $(t)$ as variables in our global model of $\Phi$ and $p$ because both parameters are known to vary 
between males and females and across years in many shorebird species (Sandercock 2003). We also modeled temporal variation as a linear $(T)$ and quadratic (TT) trend across years. Several nonexclusive factors may lead to lower apparent survival rates during the first interval after initial capture in many bird populations (Sandercock and Jaramillo 2002). Thus, we modeled $\Phi$ for the interval following initial capture $\left(\Phi^{1}\right)$ and all subsequent intervals $\left(\Phi^{2+}\right)$ separately for each gender (time-since-marking, or 2 age-class model). We did not expect $p$ to vary between first and subsequent time intervals and modeled $p$ as a function of sex and $t$. Thus, our starting global model was $\Phi^{1}{ }_{s e x^{*} t}, \Phi^{2+}{ }_{s e x^{*} t}, p_{s e x^{*} t}$.

We used two methods to assess the fit of our global model to the sandpiper survival data; a parametric bootstrap goodness-of-fit test, and the median $\hat{c}$ procedure in Program MARK (Cooch and White 2004). The parametric bootstrap goodness-of-fit procedure generated a bootstrap distribution of expected deviances through simulation ( $n=1,000$ replicates) and calculated a variance inflation factor $(\hat{c})$ as the observed deviance divided by the mean expected deviance from the bootstrap distribution (Burnham and Anderson 1998). We simulated sandpiper survival data in the median $\hat{c}$ procedure with a range of deviances ( $n=1,000$ replicates), and performed a logistic regression to estimate the median $\hat{c}$ value of the simulated data (Cooch and White 2004). Moderate amounts of overdispersion are common in mark-recapture analyses with $\hat{c}$ values of 1-3 indicating an acceptable global model fit (Lebreton et al. 1992).

We fit reduced models with fewer parameters to the sandpiper data set after examining the fit of our starting global model. We began the model selection process by modeling encounter probabilities followed by apparent survival probabilities. We contrasted models with one and two age classes $\left(\Phi\right.$ vs. $\left.\Phi^{1}, \Phi^{2+}\right)$ after modeling $p$. We modeled probabilities ( $\Phi$ and $p$ ) by initially dropping parameters from a factorial model to create additive models, and finally examined single factor and constant models. We assessed model fit with quasi-Akaike's Information Criterion, adjusted for small sample sizes $\left(\mathrm{QAIC}_{c}\right.$, Burnham and Anderson 1998). Models where $\Delta$ QAIC $_{c}$ was $<2$ from the best fit model ( $\Delta \mathrm{QAIC}_{c}$ $=0$ ) were considered equally parsimonious, and Akaike weights $\left(w_{i}\right)$ were used to evaluate the relative likelihood of a model within the set of candidate models. The ratio of $\mathrm{QAIC}_{c}$ weights between two candidate models was used to quantify the fit of a particular model to the data relative to other models (Burnham and Anderson 1998). We applied the variance components procedure in Program MARK to obtain overall estimates of apparent survival and encounter probability. We used the model averaging procedure in Program MARK to obtain annual estimates of apparent survival. Finally, we calculated the distance between annual nest attempts for site-faithful males, females, and reuniting pairs, and used analysis of variance by ranks to contrast inter-annual dispersal distances for these three groups (Kruskal and Wallis 1952). We report means $\pm \mathrm{SE}$.

\section{RESULTS}

We individually marked 533 breeding Western Sandpipers (296 females, 237 males) in the first 7 of 8 years of study. Overall return rates (individual returned to the study site in a subsequent season) were lower for females $(40 \%)$ than males $(65 \%)$. Both goodness-of-fit methods detected minor overdispersion when we fit our global model to the sandpiper survival data set (parametric bootstrap goodness-of-fit procedure $\hat{c}=2.9$; median $\hat{c}$ procedure $\hat{c}=1.4$ ). These two estimates differ, but both indicated that our global model was a satisfactory starting point $(\hat{c} \leq 3.0)$, and we chose the more conservative estimate of overdispersion $(\hat{c}$ $=2.9$ ) and continued with model selection. We systematically varied $\hat{c}$ between the two estimates after completing model selection and found no differences among the top performing models, regardless of which $\hat{c}$ value was used.

Model selection based on $\mathrm{QAIC}_{c}$ indicated the best-fit model was where survival and encounter probabilities differed between males and females but were constant over time $\left(\Phi_{\text {sex }}, p_{\text {sex }}\right.$, Table 1). Apparent survival rate of females $(0.65 \pm 0.05)$ was lower than for males $(0.78 \pm 0.03)$ as was encounter rate (females $=0.51 \pm 0.07$, males $=$ $0.74 \pm 0.04)$. Model selection revealed moderate support for a negative linear time trend model that varied between males and females $\left(\Phi_{\text {sex }}+T, p_{\text {sex }}\right.$; $\Delta \mathrm{QAIC}_{c}=1.3 ; \Phi_{\text {males 1998-2004 }}=0.82-0.75$, $\Phi_{\text {females } 1998-2004}=0.69-0.60$ ), but all $95 \%$ confidence intervals surrounding point estimates of annual apparent survival were overlapping. There also was support for a time-since-marking (2 age-class) model with variation between males and females $\left(\Phi_{\text {sex }}^{1} \Phi^{2+}{ }_{\text {sex }}, p_{\text {sex }} ; \Delta \mathrm{QAIC}_{c}=1.6 ; \Phi^{1}\right.$, 
TABLE 1. Mark-recapture models for annual estimates of apparent survival for adult Western Sandpipers breeding near Kanaryarmiut Field Station, Yukon-Kuskokwim River Delta, Alaska, 1998-2005.

\begin{tabular}{|c|c|c|c|c|}
\hline \multirow[b]{2}{*}{ Model structure ${ }^{\mathrm{b}}$} & \multicolumn{4}{|c|}{ Model statistics ${ }^{\mathrm{a}}$} \\
\hline & K & Deviance & $\Delta \mathrm{QAIC}_{c}$ & $w_{i}$ \\
\hline$\Phi_{\text {sex }}, p_{\text {sex }}$ & 4 & 122.6 & 0.0 & 0.32 \\
\hline$\Phi_{s e x+T}, p_{\text {sex }}$ & 5 & 121.9 & 1.3 & 0.16 \\
\hline$\Phi_{\text {sex }}^{1} \Phi_{\text {sex }}^{2+}, p_{\text {sex }}$ & 6 & 120.2 & 1.6 & 0.14 \\
\hline$\Phi_{s e x}+T T, p_{s e x}$ & 6 & 120.8 & 2.2 & 0.11 \\
\hline$\Phi_{\text {sex }}^{1} \Phi^{2+}{ }_{c}, p_{\text {sex }}$ & 5 & 123.1 & 2.5 & 0.09 \\
\hline$\Phi_{c}, p_{\text {sex }}$ & 3 & 127.6 & 3.0 & 0.07 \\
\hline$\Phi_{T}, p_{\text {sex }}$ & 4 & 127.2 & 4.6 & 0.03 \\
\hline$\Phi_{T T}, p_{\text {sex }}$ & 5 & 126.5 & 5.9 & 0.02 \\
\hline$\Phi_{\text {sex }}, p_{\mathrm{c}}$ & 3 & 130.8 & 6.2 & 0.01 \\
\hline$\Phi_{\text {sex }+t}^{1} \Phi_{\text {sex }+t}^{2+}, p_{\text {sex }}$ & 15 & 110.9 & 10.7 & 0.002 \\
\hline$\Phi_{\text {sex*t }}, p_{\text {sex*t }}$ & 26 & 105.3 & 28.1 & $<0.001$ \\
\hline$\Phi^{1}{ }_{s e x^{*} t} \Phi^{2+}{ }_{\text {sex* }}^{*}, p_{s e x^{*} t}$ & 37 & 97.2 & 43.5 & $<0.001$ \\
\hline
\end{tabular}

${ }^{\text {a }}$ We described model fit by the number of parameters $(K)$, deviance, and the difference in quasi-Akaike's Information Criterion $(\Delta \mathrm{QAIC})$ from the best-fit model. QAIC $c_{c}$ values were calculated using a variance inflation factor of 2.9. We present models with moderate support (Akaike weight $w_{i} \geq 0.01$ ) in order of relative fit to the best-fit model (i.e., $\Delta \mathrm{QAIC}_{c}=0$ ), followed by a two ageclass (time-since-marking) model with additive effects of sex and time, a standard Cormack-Jolly-Seber model that did not control for time since marking, and the starting global model.

bodel factors included: $\Phi^{1}=$ apparent survival during the first-year post banding, $\Phi^{2+}=$ apparent survival during subsequent years, $\Phi=$ annual apparent survival in models lacking age structure, $\mathrm{c}=$ constant, $\operatorname{sex}=$ gender, $t$ $=$ time or annual variation, $T=$ linear time trend, $T T=$ quadratic time trend, * $=\mathrm{a}$ factorial model, and $+=$ an additive model.

males $=0.72 \pm 0.06$, females $=0.57 \pm 0.08$; $\Phi^{2+}$, males $=0.81 \pm 0.04$, females $=0.69 \pm$ $0.06)$. However, the best-fit model $\left(\Phi_{s e x}, p_{s e x}\right)$ had $\geq 2$ times the support of both of these models. Model selection did not support annual variation $(t)$ in apparent survival rates $\left(\Delta \mathrm{QAIC}_{c}=7.3\right)$; however, we examined the point estimates of annual apparent survival from our global model $\left(\Phi^{1}{ }_{\text {sex* }}, \Phi^{2+}{ }_{\text {sex* }}, p_{\text {sex*t }}\right)$ because time dependence is often not supported in sparse data sets. Female apparent survival was lower in 2001 compared to other years in the interval after first capture $\left(\Phi^{1}\right)$ and later intervals $\left(\Phi^{2+}\right.$; Fig. 1).

Inter-annual dispersal distances varied among site-faithful females, males, and reuniting pairs $\left(\chi_{2}^{2}=54.2, P<0.001\right)$. Inter-annual dispersal distances were smallest among reuniting pairs (56.0 $\pm 12.3 \mathrm{~m}, n=47$ pairs). Inter-annual dispersal distances were greater among females (220.9 $\pm 27.7 \mathrm{~m}, n=66)$ compared to males $(86.9 \pm 8.5 \mathrm{~m}, n=174)$ for site-faithful individuals that did not reunite with their prior mate. We surveyed 29 plots (8.3-ha/plot) annually within a $29 \mathrm{~km}^{2}$ area surrounding our study site (15-31 May, 2004-2005). We did not detect any

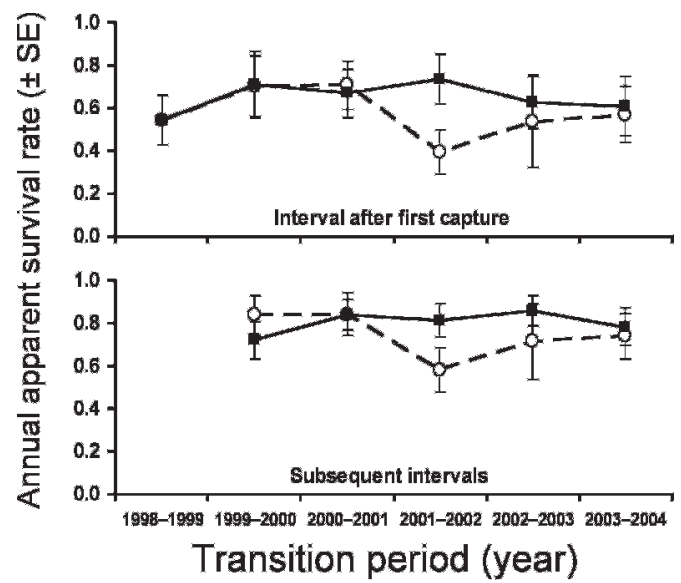

FIG. 1. Annual apparent survival rates (mean \pm SE) of adult Western Sandpipers (296 females, 237 males) breeding near Kanaryarmiut Field Station, Yukon-Kuskokwim River Delta, Alaska (1998-2005) in the interval after first capture and subsequent intervals (males $=$ squares connected with solid lines, females $=$ circles connected with broken lines). Annual estimates were calculated via model averaging, and estimates for interval 2004-2005 were not identifiable because of the time dependence in apparent annual survival and the probability of encounter.

color-marked birds during 50 hrs of observation in the surrounding region. No banded birds that went undetected in our surveys were encountered by concurrent research projects being conducted in the surrounding area (2003-2005).

\section{DISCUSSION}

We used Cormack-Jolly-Seber mark-recapture models to estimate apparent annual survival of breeding Western Sandpipers on the YukonKuskokwim River Delta, Alaska. These estimates complement those from other parts of the breeding and nonbreeding range by identifying potential temporal and spatial patterns in survival rates. Apparent survival of female Western Sandpipers was lower than males, and hierarchical model selection results indicated that apparent survival did not vary annually. Previous estimates of apparent survival for breeding Western Sandpipers also were higher for males than females (Sandercock et al. 2000), but our estimates were higher for both males and females (Table 2). Two studies also have used mark-recapture techniques to estimate the apparent annual survival of Western Sandpipers in nonbreeding areas. Juvenile and adult males in Baja California had relatively low apparent annual survival (Fernán- 
TABLE 2. Annual estimates of apparent survival for Western (Calidris mauri) and Semipalmated (C. semipalmatus) sandpipers from studies that used mark-recapture statistics for live encounter data.

\begin{tabular}{lccccccc}
\hline \multicolumn{1}{c}{ Species } & Range $^{\mathrm{a}}$ & Age $^{\mathrm{b}}$ & Gender $^{\mathrm{C}}$ & Apparent survival $^{\mathrm{d}}$ & \# birds $^{2}$ & \# years $^{\mathrm{e}}$ & Reference \\
\hline Western Sandpiper & B & A & F/M & 0.57 & 236 & 4 & Sandercock et al. 2000 \\
& NB & J & M & 0.49 & 139 & 4 & Fernández et al. 2003 \\
& & A & M & 0.45 & 117 & & \\
& NB & J/A & F & 0.62 & 1,990 & 3 & Fernández et al. 2004 \\
& & & M & 0.54 & 1,383 & & \\
Semipalmated & B & A & F & 0.65 & 296 & 8 & This study \\
Sandpiper & B & A & M & 0.78 & 237 & & \\
& & & M & 0.56 & 249 & 8 & Sandercock and Gratto-Trevor \\
& B & A & F & 0.61 & 237 & & 1997 \\
& & & M & 0.73 & 122 & 4 & Sandercock et al. 2000 \\
& NB & A & F/M & 0.65 & 215 & 4 & Rice et al. 2007 \\
& & J & F/M & 0.55 & 319 & 4 & \\
\hline
\end{tabular}

${ }^{\mathrm{a}}$ Range: $\mathrm{B}=$ breeding area, $\mathrm{NB}=$ nonbreeding area.

b Age: $\mathrm{J}=$ juveniles $\leq 1$ year of age, $\mathrm{A}=$ adults $>1$ year of age.

${ }^{\mathrm{c}}$ Gender: $\mathrm{F}=$ females, $\mathrm{M}=$ males.

d Apparent survival: estimate from best-fit model, or average of annual estimates (i.e., Sandercock and Gratto-Trevor 1997).

e \# years $=$ duration of study in years.

dez et al. 2003, Table 2), and females had higher rates of apparent annual survival than males in Chitré, Panama (Fernández et al. 2004, Table 2).

Our results are comparable to those from breeding areas for a sympatric Calidris species with similar life history characteristics. Semipalmated Sandpipers $(C$. pusilla) are small-bodied shorebirds that breed in the arctic and sub-arctic that also undertake long distance migrations and distribute themselves over a relatively large nonbreeding range (Gratto-Trevor 1992). Male Semipalmated Sandpipers near Nome, Alaska had higher apparent survival rates than females (Table 2) and both rates were similar to our estimates for Western Sandpipers. Male Semipalmated Sandpipers breeding at La Pérouse Bay, Manitoba, Canada had higher apparent survival rates than females (Table 2). These estimates were lower than ours for Western Sandpipers; however, there was considerable annual variation in that study (1980-1987, males 0.53-0.74, females 0.43-0.71; Sandercock and Gratto-Trevor 1997).

Differences between estimates of apparent survival for Western Sandpipers in this study and those from Nome may reflect temporal and/or spatial variation in survival rates. Sandercock et al. (2000) conducted their study from 1993 to 1996 at a site near Nome, Alaska. It is difficult to assess whether differences are due solely to temporal variation because the two studies were not contemporary. Survival rates vary over time in other species (e.g., Lesser Snow Goose [Anser caerulescens], Francis et al. 1992; Mallard [Anas platyrhynchos], Franklin et al. 2002; Barn Owl [Tyto alba], Altwegg et al. 2003), and this phenomenon may occur with Western Sandpipers. However, model selection results did not indicate apparent annual survival varied during the course of our study (Table 1).

Other researchers have demonstrated that demographic parameters including survival rates often vary spatially (e.g., Nichols et al. 1990, Kanyamibwa et al. 1993, Franklin et al. 2002, Pearce et al. 2005), and higher estimates of apparent survival at our study site may reflect site-specific conditions that promote higher survival compared to Nome, which is $\sim 365 \mathrm{~km}$ and $4^{\circ}$ latitude further north than our study site. Western Sandpipers breeding at Nome experience a shorter breeding season with longer periods of inclement weather compared to birds at our study site (Johnson and Walters 2008). A more severe climate coupled with longer annual migration distances may predispose birds at Nome to decreased survival.

Annual variation in apparent survival did not occur in our study population, even though it has been reported in other studies of Western Sandpipers that were of considerably shorter duration (4 years, Sandercock et al. 2000; 3 years, Fernández et al. 2003). Examination of point estimates from our global model revealed that female apparent survival was lower in 2001 compared to other years (Fig. 1). We are not able 
to account for this variation, but lower female survival in 2001 may partially explain why overall estimates of apparent survival were lower for females compared to males.

Whether lower apparent annual survival among female Western Sandpipers represents variation in true survival or sexual variation in breeding site fidelity is unknown because we are not able to differentiate the relative influence of mortality versus permanent emigration in our estimation of apparent annual survival. Males generally exhibit greater breeding site fidelity than females among monogamous sandpipers (Oring and Lank 1982, Piersma et al. 1996). We cannot conclude that female annual survivorship is lower than for males in our study population because females may exhibit lower breeding site fidelity than males. However, average inter-annual dispersal distances were relatively small in relation to size of our study site, and similar to those reported near Nome (median inter-annual dispersal distance near Nome: reuniting pairs $=38 \mathrm{~m}$, males $=48 \mathrm{~m}$, females $=157 \mathrm{~m}$ ). Further, no banded birds that went undetected in our surveys were encountered in the surrounding area. We conclude that local permanent emigration was not common at our study site.

Greater inter-annual dispersal distances among site-faithful females may indicate that females also emigrate from our study site at a higher rate than males. However, local movement patterns may or may not be indicative of larger scale dispersal patterns. Encounter probabilities were lower for females during our study, which may indicate temporary emigration (i.e., attempting reproduction at another location for 1 or more intervening years) is more common among females, or there are behavioral differences that result in lower detection rates for females. Males are more conspicuous early in the breeding season because they engage in conspicuous epigamic displays daily, whereas females are more cryptic spending greater amounts of time in concealed locations, such as wet meadows (Lanctot et al. 2000). Further, female encounter rates may be lower if only a portion of those individuals that permanently emigrate still pass through our study site before settling at other locales, or if some individuals pass through quickly and escape detection.

Western Sandpipers are a species of high conservation concern yet the underlying causes warranting this classification are unclear. Disparity between and among apparent survival estimates from breeding and nonbreeding areas highlights the need to delineate site-specific factors throughout the annual cycle that influence population dynamics of Western Sandpipers. The closely related Semipalmated Sandpiper is likely to have comparable population demographics to the Western Sandpiper (Fernández et al. 2003). Our estimates of apparent annual survival for Western Sandpipers are similar to true annual survival rates required to sustain a breeding population of Semipalmated Sandpipers $(\sim 0.80$, Hitchcock and Gratto-Trevor 1997). However, observed population declines may be misleading. Reported declines in numbers at staging sites may be caused by a shift in migration patterns (Ydenberg et al. 2004) and not by a decreasing population, further underscoring the necessity of additional research to elucidate these questions. Effective modeling and predicting population trends requires accurate estimation of vital rates encompassing the range of natural variability. Our estimates of adult survival of Western Sandpipers augment and complement previous estimates by providing current estimates from a centrally located site within the species' breeding range, and serve to better inform future conservation efforts.

\section{ACKNOWLEDGMENTS}

We thank the staff of the Yukon Delta National Wildlife Refuge for supporting this research. Financial support was received from the U.S. Fish and Wildlife Service (Yukon Delta National Wildlife Refuge), the Harold F. Bailey Fund at Virginia Tech, and the U.S. Geological Service (Forest and Rangeland Ecosystem Science Center). We thank T. L. Booms, J. R. Conklin, Z. M. Fairbanks, C. E. Fitzpatrick, L. F. Hamblin, P. N. Laver, B. L. Johnson, Silke Nebel, A. C. Niehaus, L. W. Oring, D. J. Rizzolo, and M. K. Spies for assistance in the field. G. J. Fernandez, D. B. Lank, C. A. Nicolai, C. M. Taylor, B. K. Sandercock, and two anonymous reviewers provided assistance and comments that greatly improved this manuscript. Any use of trade, or firm names is for descriptive purposes only and does not imply endorsement by the U.S. Government.

\section{LITERATURE CITED}

Altwegg, R., A. Roulin, M. Kestenholz, And L. Jenni. 2003. Variation and covariation in survival, dispersal, and population size in Barn Owls Tyto alba. Journal of Animal Ecology 72:391-399.

Bishop, M. A., P. M. Meyers, And P. F. McNeley. 2000. A method to estimate migrant shorebird numbers on the Copper River Delta, Alaska. Journal of Field Ornithology 71:627-637.

Brown, S., C. Hickey, B. Harrington, and R. Gill. 2001. The U.S. Shorebird Conservation Plan. Second 
Edition. Manomet Center for Conservation Sciences, Manomet, Massachusetts, USA.

Buenorostro, M. A., N. Warnock, And H. DE La Cueva. 1999. Wintering Western Sandpipers Calidris mauri at Estero de Punta Banda, Baja California, México. Wader Study Group Bulletin 88:59-63.

Burnham, K. P. And D. R. Anderson. 1998. Model selection and inference: a practical informationtheoretic approach. Springer-Verlag, New York, USA.

Butler, R. W. And M. J. F. Lemon. 2001. Trends in abundance of Western and Least sandpipers migrating through southern British Columbia. Bird Trends 8:3638.

Butler, R. W., G. W. Kaiser, and G. E. J. Smith. 1987. Migration chronology, length of stay, sex ratio, and weight of Western Sandpipers (Calidris mauri) on the south coast of British Columbia. Journal of Field Ornithology 58:103-111.

CARTER, R. V. 1984. A morphometric comparison of Western and Semipalmated sandpipers. Wilson Bulletin 96:277-286.

Clobert, J. AND J.-D. Lebreton. 1991. Estimation of demographic parameters in bird populations. Pages 75-104 in Bird population studies (C. M. Perrins, J.-D. Lebreton, and G. J. M. Hirons, Editors). Oxford University Press, Oxford, United Kingdom.

CoOch, E. AND G. White. 2004. Program MARK: a gentle introduction. http://www.phidot.org/software/mark/ docs/book/

EBERHARDT, L. L. 1985. Assessing the dynamics of wild populations. Journal of Wildlife Management 49:9971012.

ESRI INC. 2007. ArcGIS. Version 9.2. Earth Systems Research Institute Inc., Redlands, California, USA.

Evans, P. R. AND M. W. Pienkowski. 1984. Population dynamics of shorebirds. Pages 83-123 in Behaviour of marine animals (J. Burger and B. L. Olla, Editors). Volume 5. Plenum Press, New York, USA.

FERnÁndez, G., P. D. O'HARA, AND D. B. LANK. 2004 Tropical and subtropical Western Sandpipers (Calidris mauri) differ in life history strategies. Ornitologia Neotropical 15:385-394.

Fernández, G., H. DE la Cueva, N. Warnock, AND D. B. LANK. 2003. Apparent survival rates of Western Sandpipers (Calidris mauri) wintering in northwest Baja California, Mexico. Auk 120:55-61.

FernándeZ, G., N. WARNock, D. L. LANK, AND J. B. Buchanan. 2006. Version 1.1. Conservation Plan for the Western Sandpiper. Manomet Center for Conservation Science, Manomet, Massachusetts, USA.

Francis, C. M., M. H. Richards, F. COOKE, AND R. F. ROCKWELL. 1992. Long-term changes in survival rates of Lesser Snow Geese. Ecology 73:1346-1362.

Franklin, A. B., D. R. ANDERson, ANd K. P. Burnham. 2002. Estimation of long-term trends and variation in avian survival probabilities using random effects models. Journal of Applied Statistics 29:267-287.

Gratto-Trevor, C. L. 1992. Semipalmated Sandpiper (Calidris pusilla). The birds of North America. Number 6.

Haig, S. M. C. L. Ferland, F. J. Cuthbert, J.
Dingledine, J. P. Goossen, A. Hecht, AND N. MCPHILLIPS. 2005. A complete species census and evidence for regional declines in Piping Plovers. Journal of Wildlife Management 69:160-173.

HagemeiJer, E. J. M. AND M. J. BlaiR. 1997. The EBCC Atlas of European breeding birds: their distribution and abundance. T. \& A. D. Poyser, London, United Kingdom.

HARRINGTON, B. AND B. HAASE. 1994. Latitudinal differences in sex ratios among nonbreeding Western Sandpipers in Puerto Rico and Ecuador. Southwestern Naturalist 39:188-189.

HiLl, D. AND N. CARTER. 1991. An empirical simulation of an Avocet Recurvirostra avosetta population. Ornis Scandinavica 22:65-72.

HitchCock, C. AND C. L. GRATTO-TREVOR. 1997. Diagnosing a shorebird local population decline with a stagestructured population model. Ecology 78:522-534.

HolmES, R. T. 1971. Density, habitat and the mating system of the Western Sandpiper (Calidris mauri). Oecologia 7:191-208.

Howe, M. A., P. H. Geissler, and B. A. Harrington. 1989. Population trends of North American shorebirds based on the International Shorebird Survey. Biological Conservation 49:185-199.

JoHnSON, M. AND L. W. ORING. 2002. Are nest exclosures an effective tool in plover conservation? Waterbirds 25:184-190.

JOHNSON, M. AND J. R. WALTERS. 2008. Effects of mate and site fidelity on nest survival of Western Sandpipers. Auk 125:76-86.

JOHNSON, M., S. E. JAMIESON, AND B. J. MCCAFFERY. 2005. Arctic breeding conditions locality report: Kanaryarmiut Field Station, Yukon Delta National Wildlife Refuge. Arctic Birds 7:26-28.

JoRGENSON, T. AND C. ELY. 2001. Topography and flooding of coastal ecosystems on the Yukon-Kuskokwim Delta, Alaska: implications for sea-level rise. Journal of Coastal Research 17:124-136

Kanyamibwa, S., F. Bairlein, And A. Schierer. 1993. Comparison of survival rates between populations of the White Stork Ciconia ciconia in central Europe. Ornis Scandinavica 24:297-302.

KRUSKAL, W. H. AND W. A. WALLIS. 1952. Use of ranks in one-criterion analysis of variance. Journal of the American Statistical Association 47:583-621.

Lanctot, R. B., B. K. Sandercock, and B. Kempenaers. 2000. Do male breeding displays function to attract mates or defend territories? The explanatory role of mate and site fidelity. Waterbirds 23:155-164.

LANDE, R. 1988. Demographic models of the Northern Spotted Owl (Strix occidentalis caurina). Oecologia 75:601-607.

Larson, M. A., M. R. Ryan, and R. K. Murphy. 2002. Population viability of Piping Plovers: effects of predator exclusion. Journal of Wildlife Management 66:361-371.

Lieske, D. J., I. G. Warkentin, P. C. James, L. W. OliPHANT, AND R. H. M. EsPIE. 2000. Effects of population density on survival in Merlins. Auk 117:184-193. 
Lebreton, J.-D. AND P. M. North. 1993. Marked individuals in the study of bird populations. Birkhäuser Verlag, Basel, Switzerland.

Lebreton, J.-D., R. Pradel, and J. Clobert. 1993. The statistical analysis of animal populations. Trends in Ecology and Evolution 8:91-95.

Lebreton, J.-D., K. P. Burnham, J. Clobert, and D. R. ANDERSON. 1992. Modeling survival and testing biological hypotheses using marked animals: a unified approach with case studies. Ecological Monographs 62:67-118.

Morrison, R. I. G, R. E. Gill JR., B. A. Harrington, S. Skagen, G. W. Page, C. L. Gratto-Trevor, and S. M. HAIG. 2000. Population estimates of Nearctic shorebirds. Waterbirds 23:337-352.

Morrison, R. I. G., Y. Aubry, R. W. Butler, G. W. Beyersbergen, G. M. Donaldson, C. L. GrattoTrevor, P. W. Hicklin, V. H. Johnston, AND R. K. Ross. 2001. Declines in North American shorebird populations. Wader Study Group Bulletin 94: 34-38.

Nebel, S., D. B. Lank, P. D. O’Hara, G. Fernández, B. Haase, F. Delgado, F. A. Estela, L. J. Evans Ogden, B. Harrington, B. E. Kus, J. E. Lyons, F. Mercier, B. Ortego, J. Y. TAKEKAWA, N. WARNOCK, AND S. E. WARNOCK. 2002. Western Sandpipers (Calidris mauri) during the nonbreeding season: spatial segregations on a hemispheric scale. Auk 119:922-928.

NEIL, R. L. 1992. Recent trends in shorebird migration for north-central Texas. Southwestern Naturalist 37:87-88.

Nichols, J. D., M. Williams, AND T. CAithness. 1990. Survival and band recovery rates of Mallards in New Zealand. Journal of Wildlife Management 54:629-636.

O'Hara, P. D., G. Fernández, F. Becerril, H. de al Cueva, And D. B. LANK. 2005. Life history varies with migratory distance in Western Sandpipers Calidris mauri. Journal of Avian Biology 36:191-202.

ORING, L. W. AND D. B. LANK. 1982. Sexual selection, arrival times, philopatry, and site fidelity in the polyandrous Spotted Sandpiper. Behavioral Ecology and Sociobiology 10:185-191.

Page, G. AND B. Fearis. 1971. Sexing Western Sandpipers by bill length. Bird-Banding 42:297-298.

Page, G., B. Fearis, And R. M. Jurek. 1972. Age and sex composition of Western Sandpipers on Bolinas Lagoon. California Birds 3:79-86.

Pearce, J. M., J. A. Reed, And P. L. Flint. 2005. Geographic variation in survival and migratory tendency among North American Common Mergansers. Journal of Field Ornithology 76:109-118.

Piersma, T. AND A. J. BAKER. 2000. Life history characteristics and the conservation of migratory shorebirds. Pages 105-124 in Behaviour and conservation (L. M. Gosling and W. J. Sutherland, Editors). Cambridge University Press, Cambridge, United Kingdom.

Piersma, T., J. VAn Gils, and P. Wiersma. 1996. Family Scolopacidae (Sandpipers, Snipes and Phalaropes). Pages 444-487 in Handbook of the birds of the world, Volume 3, Hoatzin to Auks (J. del Hoyo, A. Elliott, and J. Sargatal, Editors). Lynx Edicions, Barcelona, Spain.
Piersma, T., P. Wiersma, And J. VAn Gils. 1997. The many unknowns about plovers and sandpipers of the world: introduction to a wealth of research opportunities highly relevant for shorebird conservation. Wader Study Group Bulletin 82:23-33.

Plissner, J. H. AND S. M. HAIG. 2000. Viability of Piping Plover Charadrius melodus metapopulations. Biological Conservation 92:163-173.

ReED, J. M., C. S. ElPhICK, AND L. W. ORING. 1998. Lifehistory and viability analysis of the endangered Hawaiian Stilt. Biological Conservation 84:35-45.

Rice, S. M., J. A. Collazo, M. W. Alldredge, B. A. HaRrington, AND A. R. Lewis. 2007. Local annual survival and seasonal residency rates of Semipalmated Sandpipers (Calidris pusilla) in Puerto Rico. Auk 124:1397-1406.

Rose, P. M. AND D. A. SCOTT. 1997. Waterfowl population estimates. Second Edition. Wetlands International Publication 44. Wageningen, The Netherlands.

SANDERCOCK, B. K. 2003. Estimation of survival rates for wader populations: a review of mark-recapture methods. Wader Study Group Bulletin 100:163-174.

SAndercock, B. K. And C. L. Gratto-Trevor. 1997. Local survival in Semipalmated Sandpipers Calidris pusilla breeding at La Pérouse Bay, Canada. Ibis 139:305-312.

SANDERCOCK, B. K. AND A. JARAmILlO. 2002. Annual survival rates of wintering sparrows: assessing demographic consequences of migration. Auk 119:149165.

SAndercock, B. K., D. LANK, AND F. CoOKe. 1999. Seasonal declines in the fecundity of two arcticbreeding sandpipers: different tactics in two species with an invariant clutch size. Journal of Avian Biology 30:460-468.

SANDERCOCK, B. K., D. B. LANK, R. B. LANCTOT, B. Kempenaers, AND F. COOKe. 2000. Ecological correlates of mate fidelity in two arctic-breeding sandpipers. Canadian Journal of Zoology 78:19481958.

Senner, S. E., D. W. Norton, And G. C. West. 1981. The spring migration of Western Sandpipers and Dunlins in southcentral Alaska: numbers, timing, and sex ratios. Journal of Field Ornithology 52:271-284.

Tucker, G. M. AND M. HeATH. 1994. Birds in Europe: their conservation status. Birdlife Conservation Series Number 3. Birdlife International, Cambridge, United Kingdom.

WiLson, W. H. 1994. Western Sandpiper (Calidris mauri). The birds of North America. Number 90.

YdenberG, R. C., A. C. Niehaus, and D. B. Lank. 2005. Interannual differences in the relative timing of southward migration of male and female Western Sandpipers (Calidris mauri). Naturwissenschaften 92: 332-335.

YdenberG, R. C., R. W. Butler, D. B. LANK, B. D. SMith, AND J. IRELAND. 2004. Western Sandpipers have altered migration tactics as Peregrine Falcon populations have recovered. Proceedings of the Royal Society of London, Series B 271:1263-1269. 